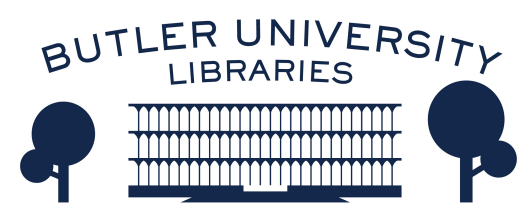

Journal of Hindu-Christian Studies

\title{
Book Review: Caste, Gender, and Christianity in Colonial India: Telugu Women in Mission
}

Kerry P. C. San Chirico

Villanova University

Follow this and additional works at: https://digitalcommons.butler.edu/jhcs

Part of the Christianity Commons, Hindu Studies Commons, and the Religious Thought, Theology and Philosophy of Religion Commons

\section{Recommended Citation}

San Chirico, Kerry P. C. (2017) "Book Review: Caste, Gender, and Christianity in Colonial India: Telugu Women in Mission," Journal of Hindu-Christian Studies: Vol. 30, Article 20.

Available at: https://doi.org/10.7825/2164-6279.1672

The Journal of Hindu-Christian Studies is a publication of the Society for Hindu-Christian Studies. The digital version is made available by Digital Commons @ Butler University. For questions about the Journal or the Society, please contact cbauman@butler.edu. For more information about Digital Commons @ Butler University, please contact digitalscholarship@butler.edu. 
Dalit conversions. It, however, falls prey to the temptation of giving Gandhi more space in the conversation than he deserves.

With this chapter, Roberts subtly but brilliantly locates the stories of slum Christians in the larger context of religious conversions in India. He prepares the reader to understand the slum religion he would discuss in the following three chapters. Readers unacquainted with the history of urbanization in India and migration of Dalits to the cities during the colonial era would have benefitted from a concise history of this slum and the roots of this slum religion.

The final three chapters explicate and interpret the religious world(s) of the slum residents. Roberts identifies the similarities between the beliefs of Hindu and Christian residents and highlights the fluidity of boundaries between the two. He also outlines the differences. He incisively defines what he means by these categories and delineates how different are these from Hinduisms and Christianities elsewhere. The use of simple binaries might sometimes exclude those residents who do not identify themselves as neither and refuse to worship Hindu and Christian gods. The discussion about pastoral authority and the rumors that surround them highlight the power dynamics in the slum religion. Parsing the prayers of the residents, Roberts examines the social significance of prayer. He then illustrates the theme of suffering and the countercultural ethos of slum Christianity with the story of Umbrella Preacher. Roberts deftly uses Rupa Viswanath's findings about Dalits' use of, or lack thereof, umbrellas a century ago to interpret Umbrella Preacher's religion and thus illustrates slum Christianity.

This book is a welcome addition to the conversations on conversions, especially in the light of anti-conversion legislations in India. Robert's keen observation of the world of the community under study and a critical appreciation towards it make this book credible. His incisive, lively and lucid writing style makes it readable and engaging. Nathaniel Roberts should be commended for this gift to the fields of religion in South Asia, World Christianity and Popular Hinduism.

James Elisha Taneti

International Theological Center, Atlanta

\section{Caste, Gender, and Christianity in Colonial India: Telugu Women in Mission. By James Elisha Taneti. New York: Palgrave Macmillan, 2013, 203 pages.}

HOW does one give voice to those whose own voices were historically marginalized or mostly unrecorded and whose significance therefore can easily go unacknowledged? Postcolonial history requires the best of the historian's abilities-to command archival material, to cautiously infer, to suggest, to apply intelligence and imagination, and to thereby offer plausible interpretations. This James Elisha Taneti does admirably in the 2013 installment in the Palgrave Macmillan's Postcolonialism and Religions series.

The text concerns itself with a category of Protestant church worker often mentioned but still under-examined. These are Biblewomen, women in the $19^{\text {th }}$ and first half of the $20^{\text {th }}$ 
centuries who disseminated and taught Scripture throughout the world. Animated by evangelical Protestant faith, they sold Bibles, interpreted them, told and sang Bible stories to the illiterate and children, taught hygiene, advocated temperance, and modeled notions of Christian womanhood and femininity. They were boundary crossers. And here we must get particular, for the text concerns itself not so much with Biblewomen writ large, but with a particular region of British India, the Northern Circars, or what is now modern-day coastal Andhra Pradesh. These women, numbering in the hundreds by the early 1900s, moved in what Mary Louise Pratt calls "contact zones," journeying physically and culturally between indigenous Hindu Telugu peoples of various caste backgrounds, Western missionaries, and emerging Telugu Protestant Christian communities they helped to build. In the process, they created something new that went beyond sharing the Christian message: their work increased literacy and education, and, perhaps most importantly, suggested a novel vision of the possibilities for women (Indian and European) given the profound changes wrought by British colonialism.

It is a point made by Dana Robert and others that the modern missionary movement was in fact a woman's movement. By the early 1900s, the heyday of the Western Christian missionary activity and Western colonialism, women constituted the vast majority of missionaries throughout the globe. India was no exception. Nor was this, as suggested by then contemporary celebratory accounts of Western missionaries, primarily a story of intrepid white male Gospel explorers. The missionaries were far outnumbered by Indians and female ones at that, even as males held the dominant, usually ordained, ecclesial and other intuitional positions. Although Biblewomen occupied the lower wrung of the mission hierarchy, they were irreplaceable.

Like more recent studies, Taneti takes it as a given that Indian Biblewomen demonstrated agency; they were not passive recipients of a foreign religion, empty vessels to be filled up by a foreign ideology. Nor were they rendered immediately alien by the adoption of the colonizer's religion, as though both nature and nurture are washed away in baptismal waters. What Taneti adds to postcolonial studies, joining Anupama Rao and Uma Chakravarti, is his accounting for gender and caste in his understanding of the significance of Telugu Biblewomen. Like these scholars, he takes gender and caste diversity into account, thus successfully avoiding reproduction of Brahmanical norms in studies of lower castes even as it is obvious that Telugu Biblewomen, like their European missionary colleagues, typically contended with and often circumvented Brahmanical norms, a point to which I shall return in a moment.

Along with conversation partners in postcolonial studies, the scholar situates himself among other notable examinations of Biblewomen in other Indian contexts, particularly Eliza Kent and Jane Haggis, as well as scholars focusing on the office in other parts of the world. These include Deborah Gaitskell (South Africa), Wendy Urban-Mead (Zimbabwe) Vanessa Wood, Valerie Griffiths, Ellen Xiang-Yu Cai, Jessie Lutz, and Ling Oi Ki (China). Taneti doesn't offer a new paradigm for studying Biblewomen as much as bring another region to our knowledge while adding greater precision to our understanding of Biblewomen in general and in the Northern Circars in particular. He 
offers a necessary corrective to the narrative of missionary activity as either belonging to primarily Western male and female missionaries on the one hand (the view through much of the $20^{\text {th }}$ century), or the understandable overreaction (of the late $20^{\text {th }}$ century) that indigenous male missionaries were the primary drivers of the missionary movement. "While not denying both narratives," he explains, "this case submits that native women were equally responsible for the expansion and articulation of Christianity in the region under study, as in other areas of the world" (21). These issues are helpfully framed in the Introduction.

Chapter 2, "Foremothers and Foreign Sisters," focuses on the development of Christianity in the Northern Circars, then explains the advent of the Biblewoman in early $19^{\text {th }}$ century England. Chapter 3, "The Meeting of Two Worlds in One Office: 1880-1921," explains the factors that shaped the development of Telugu Biblewomen, namely the office as it existed in Britain, Dalit conversions and the subsequent ascendency of Dalit women to the office, the effects of local cultural changes, and the increasing "feminization" of the missionary movement. In Chapter 4, "Institutionalizing a Ministry," the scholar explores the process by which mentorships gave way to the founding of women's seminaries, and as the nationalist movement became more critical of missionary activity. Chapter 5 takes a comparative, global turn, with an examination of the Telugu Biblewomen in relation to their sisters around the world in order to demonstrate unique Telugu Biblewomen characteristics. In a rather terse conclusion, the author recapitulates the significant factors in the development of the office. One wishes there had been more metareflection on Biblewomen, discussing its implications for understanding Indian Christianity, missionary activity, and a discussion, even conjectural, of Biblewomen's influence on Indian society, first during the late $19^{\text {th }}$ century, then as Independence loomed. An Appendix, a letter of one of the first British Biblewomen, Marian Bowers, is included. The Notes are copious and the Bibliography and Index will prove useful to readers of this text and to those interested in delving more deeply into the subject matter with all its attendant features.

of special interest to this reader were the ways they navigated the movement between contact zones through creative melding of indigenous and foreign cultural norms. For example, most Biblewomen were Dalits. In the Northern Circars, Dalit women were responsible for much village-based cultic activity in the region where they served as intermediaries to goddesses across caste divisions. Moreover, "Dalit Christians brought with them female preaching, which was a distinctive mark of Dalit religiosity" (55). This, coupled, with hygienic practices adopted from the Western missionaries (that shared an affinity with Brahmanical purity expectations) often allowed low-caste Biblewomen to move in high caste spaces. Such movement was a larger part of colonial disruption. Whereas Brahmanical norms traditionally prevented physical and social mobility, "the colonial environment facilitated these subversive travels both on the subcontinent and overseas" (79). As Taneti demonstrates, “...Telugu Biblewomen were unconsciously participating in a larger process of social disruption" (81). And this disruption was equally economic: interestingly enough, Biblewomen were some of the first women to be compensated in cash, much to the consternation 
of males; and many Biblewomen raised their children as they conducted their church vocation. One is left to ponder, among other things, just how unconscious these subversive activities were. And what was their influence on broader society? on Dalits who never converted? on Western missionaries who never had the kind of access granted to their indigenous sisters? on women's roles among Telugu-speaking Christians to this day? Such questions lead inevitably, thankfully, to further research.

Kerry P. C. San Chirico

Villanova University

\section{Constructing Indian Christianities: Culture, Conversion, and Caste. Edited by Chad M. Bauman and Richard Fox Young. Abington, UK: Routledge, 2014, xxiii + 264 pages.}

CONSTRUCTING Indian Christianities, ably edited by Chad Bauman and Richard Fox Young, problematizes conventional approaches to understanding Indian Christianity. As the title of the volume makes clear, the essays collectively portray Christianity in India as pluriform and thereby challenge theories that deploy univocal or tightly bounded categories and tropes. The ten chapters of Constructing Indian Christianities are organized around three interrelated questions: who and what is an Indian Christian; whose religion is Indian Christianity; and can Christianity be Indian. Taken as a whole, the essays included in the volume provide a number of oblique and profitable entries into considering Indian Christianity in situ as very much part of the complex dynamics of Indian life.

The first section, "Who and What is an Indian Christian?", is composed of three wellexecuted ethnographic vignettes that are part of larger studies. Miriam Bentler considers "Spiritual Parenthood" among Kerala's Latin Catholic community and examines how Southern European and South Indian kinship systems have together developed and changed in interesting ways. Kerry San Chirico raises questions about conversion as a conceptual category in his consideration of North India's Khrist Bhakta movement, which is composed of Hindu devotees of Christ who remain unbaptized. Ashok Kumar's piece rounds out the section by discussing how Dalit Christians in Andhra Pradesh have responded to governmental discrimination by interlocking caste and congregation. The essays in this section present their ethnographic data clearly and concisely, which makes their theoretical points all the stronger.

The four essays in the second section, "Whose Religion is Indian Christianity?," range broadly. Gulfshan Khan examines the discourse surrounding Catholicism at the Mughal Court and maintains a complex discussion that concludes by arguing that it was not only the Quranic understanding of Jesus that prevailed in Agra but also that which substantively drew upon Jesuit sources. In "Authority and Patronage: Protestant Devotion and the Development of the Tamil Hymn in Colonial 